\title{
Effects of suspended matter quality and virus abundance on microbial parameters: experimental evidence from a large European river
}

\author{
Lisa Kernegger, Irene Zweimüller, Peter Peduzzi*
}

Department of Freshwater Ecology, Faculty of Life Sciences, University of Vienna, Althanstrasse 14, 1090 Vienna, Austria

\begin{abstract}
In riverine water, both suspended particulate material and viruses are prominent ecological factors. The existence of various particle types and differences in viral abundance impose variability in microenvironments. Particulates and their microbial surrounding may interact in several ways, this interaction being strongly dependent on particle quality and the abundance of organisms involved. In laboratory experiments, we used different suspended matter types (fresh and aged mineral sediment and leaf litter, river snow) that typically occur in riverine environments as model particles. We investigated the effects of particle quality and different ambient viral abundances $(\times 1$, $\times 2$ enrichments, and inactivated viruses) on several microbial parameters (changes in bacterial and viral abundances, bacterial production, specific bacterial production) of both the free-living and particle-attached fractions using water from a floodplain system of the Danube River (Austria). Both seston quality and variable viral abundances in the bulk water influenced some microbial parameters. The average abundance of bacteria and viruses was significantly higher on organic than on inorganic particles and on aged particles (for both sediment and leaf litter). Changes in bacterial abundance during the course of the experiments were also influenced by particle quality, with, for example, aged sediment favoring increasing abundances. Virus:bacterium ratios (VBR) were significantly higher on organic than on inorganic particles, but significantly lower on suspended particles than in the planktonic fraction. Typically, bacterial secondary production (overall and cell-specific) was higher on particles than in bulk water. Bacterial productivity in the ambient water was negatively affected by the abundance of planktonic viruses but positively affected by that of attached viruses. These findings from experimental systems may foster in situ studies of particle-rich environments.
\end{abstract}

KEY WORDS: Virus $\cdot$ Particles $\cdot$ Suspended matter $\cdot$ River $\cdot$ River snow

\section{INTRODUCTION}

The presence of suspended particulate matter and its variable quality in various aquatic environments can considerably affect the microbial community (Simon et al. 2002, Peduzzi \& Luef 2008). Due to the multiple sources of particles in inland waters, their environmental significance may vary strongly between and even within particular systems (compare e.g. Hopkinson et al. 1998). In riverine systems, auto- and allochthonous sources yield a composite of inorganic and organic suspended materials (Hein et al. 2003). Such particles may be subjected to substantial alteration in size and chemical composition. They are usually converted from larger to finer size through physical and biological maceration, although some processes like formation of fecal pellets or aggregation may also increase particle size (Johnson et al. 1986, Ward et al. 1990). The nonliving matrix of particles and aggregates can harbor a rich microbial community. Aggregates tend to be amorphous, porous structures exhibiting high nutrient concentrations, a diverse microbial assemblage and polymer glycoconjugate distribution, as well as distinctive physical and chemical gradients (Neu 2000, Simon et al. 2002, Luef et al. 2009). When they are large enough to be seen macroscopically in riverine environments, the term 'river snow' is used for such aggregates in analogy to marine snow (Neu 2000). It can be 
assumed that particle-microbe interactions strongly depend on particle quality, and the type and abundance of organisms involved.

Viruses are abundant in all natural aquatic environments, with abundances varying from $<10^{4} \mathrm{ml}^{-1}$ to $>10^{8} \mathrm{ml}^{-1}$ (Wommack \& Colwell 2000). Moreover, their abundance is generally one order of magnitude higher than that of bacterioplankton (Weinbauer 2004). They can therefore significantly affect bacterio- and phytoplankton (Proctor \& Fuhrman 1990, Suttle et al. 1990). Viruses and suspended particulate material may interact in several ways that can be ecologically relevant in aquatic environments. In a previous study using thin sectioning and transmission electron microscopy (TEM), we found up to $9 \times 10^{10}$ virus particles $\mathrm{cm}^{-3}$ in marine snow of the northern Adriatic Sea; these viruses were able to influence the process of algal floc formation (Peduzzi \&Weinbauer 1993a). Although suspended matter is often a prominent factor in inland waters, only limited data on the abundance of viruses associated with suspended particulate material in freshwater exist (Luef et al. 2007, Peduzzi \& Luef 2008, Peduzzi \& Luef 2009). Riverine systems display highly variable particle loads that are mainly triggered by hydrology. In the Danube River where suspended matter is often a prominent factor, a variable and occasionally high proportion of viruses (between 0.43 and $35.06 \%$ ) was found to be associated with particulate material (Luef et al. 2007). A recent study reports up to $5.4 \times 10^{9}$ viruses $\mathrm{cm}^{-3}$ lectin-stained suspended material in the Danube as analyzed by confocal laser scanning microscopy (Luef et al. 2009). However, interactions between suspended matter and natural viral assemblages are poorly documented.

We performed laboratory experiments to (1) test the effect of particle quality on the dynamics of prokaryotic and viral abundance, both on the particles and in the surrounding water, and (2) assess how different ambient viral abundances are involved in this interaction. The experiments were conducted with water from a floodplain of the Danube River (Austria), using 3 different suspended matter types (mineral sediment, leaf litter and river snow) that typically occur in this environment as model particles. We also differentiated the particulate material as 'organic or inorganic' and 'fresh or aged'. We hypothesized that (1) growth conditions for prokaryotes are generally better on particulate material, (2) organic material should be more attractive to microorganisms (bacteria and viruses), and (3) aged particles are more densely populated by microorganisms than freshly produced material. We further hypothesized that (4) differences in the abundance of free-living and attached viruses affect the productivity of prokaryotic plankton.

\section{MATERIALS AND METHODS}

Sampling and incubation. All water samples for the experiments were taken from a floodplain section of the Danube River, downstream of Vienna at Regelsbrunn, in the Danube National Park at river kilometer 1895. In Austria, the Danube River is a 9th order river, and the reach downstream of Vienna represents one of the last remnants of semi-natural river floodplain systems in central Europe, although it is strongly impacted by regulation. This running water system carries various particle loads depending on hydrological and biological conditions. The area has been the site of intense research activities in recent years (e.g. Hein et al. 1999, Besemer et al. 2005, Luef et al. 2007, Peduzzi \& Luef 2008, Peduzzi et al. 2008). Sampling of water for the experiments was conducted during a period of moderate water level fluctuations. Experiments were carried out in the laboratory using rotating tanks (10 l, translucent acrylic glass, washed with $10 \% \mathrm{HCl}$, tap water and finally rinsed with Milli-Q water) on a rolling table at $2 \mathrm{rpm}$.

Processing of bacterial and viral concentrates. For each experiment, water was taken from the sampling site at Regelsbrunn and treated as follows (Fig. 1): the water was prefiltered through a $3 \mu \mathrm{m}$ mesh, then through a GF/C (Gelman Sciences fiber filter type A/C glass, nominal pore size $1.2 \mu \mathrm{m}, 142 \mathrm{~mm}$ diameter) and finally through a $0.22 \mu \mathrm{m}$ GV Millipore membrane filter (142 mm diameter). A bacterial concentrate was produced from $40 \mathrm{l}$ of $1.2 \mu \mathrm{m}$ prefiltered water, which was again filtered onto a $0.22 \mu \mathrm{m}$ GV Millipore membrane filter (47 mm diameter). Bacteria were kept in suspension by gentle stirring with a glass rod, taking care that a residual volume remained in the filter funnel. After decanting, the used filters were rinsed in the bacterial concentrate to recover most of the cells. This yielded a bacterial concentrate of $\sim 3.4 \times 10^{7}$ cells ml $^{-1}$. To produce a viral concentrate, ultrafiltration (Millipore Pro Flux M12) was used. A $100 \mathrm{l}$ volume of $0.22 \mu \mathrm{m}$ prefiltered water was ultrafiltered as described by Suttle et al. (1991). The 2 obtained fractions are the retentate (viral concentrate) and the permeate (virus-free water; Weinbauer 2004). A $30 \mathrm{kDa}$ cut-off cartridge efficiently concentrated the virus size fraction (Suttle et al. 1991). The resulting viral concentrate contained $\sim 1.8 \times 10^{9}$ viral particles $\mathrm{ml}^{-1}$.

Processing of particles. Three different particle types (inorganic sediment, leaf litter and river snow) were used. Sediment and leaf litter particles were used in 2 ways: as 'fresh' particles to represent freshly introduced material into the aquatic environment (e.g. during spates; in this case, particles were free of microorganisms at the beginning of the experiment); and as 'aged' particles that were covered with an already formed aquatic biofilm. River snow was used as it was (see below). 


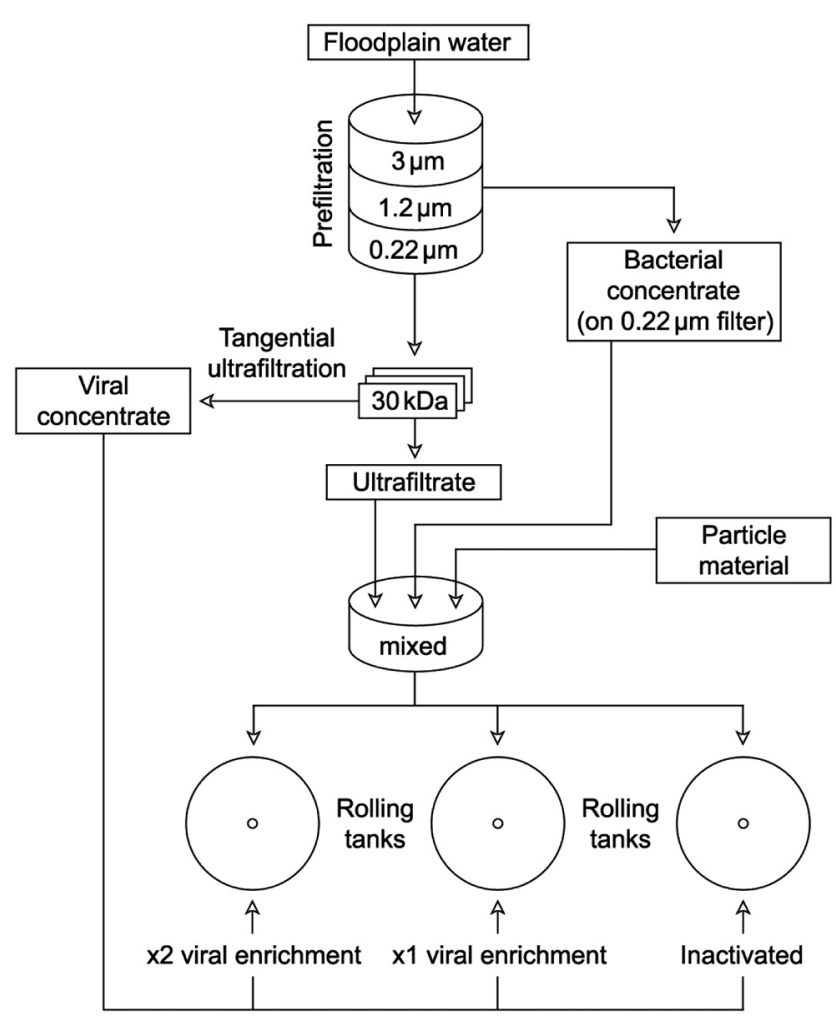

Fig. 1. Preparation (filtration and concentration) of samples for culture experiments in rotating tanks. Different particulate materials were added (see 'Materials and methods' for details); treatments were enriched with 2 different virus abundances and with inactivated viruses

Sediment: Sediment was taken from the sampling site. It was cleaned of organic matter in a muffle furnace at $480^{\circ} \mathrm{C}$ for $6 \mathrm{~h}$. For the experiment that was initially without particle-associated microorganisms (fresh sediment treatment), $25 \mathrm{~g}$ of this mineral sediment was transferred into each rolling tank.

To produce aged sediment, the cleaned sediment was placed into an aquarium with $30 \mathrm{l}$ of sample water that had been GF/C (Gelman Sciences fiber filter type $\mathrm{A} / \mathrm{C}$ glass, $1.2 \mu \mathrm{m}$ ) filtered. The aquarium was previously rinsed with $10 \% \mathrm{HCl}$, tap water, Milli-Q water and filtered sample water (in that order). Air was pumped into the aquarium to keep sediment in suspension. After $6 \mathrm{~d}$ (a period reflecting typical retention times of water at the source location of the Danube River floodplain; Hein et al. 1999), this aged sediment was transferred into the experimental rolling tanks (see below).

Leaf litter: Leaf litter was collected from the shore at the sampling site. It was rinsed twice with tap water and once with deionized water. After drying at $60^{\circ} \mathrm{C}$ for $48 \mathrm{~h}$, leaves were crushed and sieved through a
$1 \mathrm{~mm}$ mesh. For the respective experiment, $220 \mathrm{mg}$ of these dried leaf particles ( $<1 \mathrm{~mm}$ particle size) was added into each rolling tank. To produce leaf litter with biofilm, dried leaf particles were placed in an aquarium and processed similarly as the aged mineral sediment.

River snow: Unprocessed sample water was added into rolling tanks. The tanks were kept rotating under artificial light (daylight spectrum, $300 \mu \mathrm{mol} \mathrm{m}^{-2} \mathrm{~s}^{-1}$ ) at $2 \mathrm{rpm}$ for $4 \mathrm{~d}$ to form suspended river snow particles as described by Shanks \& Edmondson (1989). For the respective set of experimental incubations, the river snow particles were carefully transferred into clean rolling tanks containing experimental water (see next section).

Experimental setup in rolling tanks. For each experimental setup with different particulate material, 3 sets of rolling tanks were prepared and incubated for $60 \mathrm{~h}$ (Fig. 1). The 3 sets of rolling tanks had the same initial bacterial abundance and equal density of the respective particle type but different viral concentrations. Although all analyses were carried out in duplicate or triplicate, it was not possible to replicate batch cultures for each treatment due to the complexity of the experimental protocol (cf. Auguet et al. 2009). For each set of rolling tanks, microorganism-free water (30 kDa permeate) was placed in a large jar. Approximately $1.5 \mathrm{l}$ of bacterial concentrate as well as particles were added and gently stirred to obtain a homogeneous suspension of bacteria and particles. This suspension was split and added into each tank of the 3 experimental treatments. The viral concentrate was added separately; the 3 different treatments received different viral concentrations (see below). Aged particles were transferred from the aquarium to the rolling tanks as follows: water from the aquarium was poured through a $3 \mu \mathrm{m}$ mesh to collect the particles, which were then resuspended in microorganism-free water. To ensure that each tank received approximately the same amount of particles, this particle slurry was poured into graduated flasks, stirred to keep particles suspended and equal aliquots were then distributed into the rolling tanks. Particles without initial colonization were weighed and equal amounts of dried particles were transferred directly into each tank.

The preparation of the river snow treatment differed from that of the other 4 particle types. River snow particles were carefully pipetted from the tank where they had been produced into a large Petri dish. Almost all water in the Petri dish was carefully removed while ensuring that particles did not dry up, before transferring river snow particles into the tanks in approximately equal amounts.

Virus-free treatment: To investigate whether viruses have any impact at all, a 'virus-free' (i.e. with inacti- 
vated viruses) incubation was also conducted with each particle type as a control. Microwave treatment was applied to inactivate heat-labile viruses (Proctor \& Fuhrman 1992). A $200 \mathrm{ml}$ volume of the viral concentrate was treated at the highest power output of a microwave oven $(500 \mathrm{~W})$ for $3 \mathrm{~min}$ at $30 \mathrm{~s}$ intervals, with the sample being iced down between microwave exposures to prevent boiling. This procedure has also been used in other studies (e.g. Weinbauer \& Suttle 1996, Auguet et al. 2009) and was found to successfully inactivate viruses (Auguet et al. 2009).

Treatments with different viral concentrations: To cover the range of viral abundances typically occurring at the sampling location, 2 different viral abundances ('low virus' and 'virus-rich') were used in these experiments. A $100 \mathrm{ml}$ volume of the untreated viral concentrate was added by gentle stirring (Fig. 1). The initial viral concentration obtained in this low viral concentration treatment was half the viral concentration of the 'virus-rich' treatment. The latter was obtained by transferring $200 \mathrm{ml}$ of the viral concentrate into the tank.

Bacterial and viral abundance measurements. The technique for enumerating microorganisms that was applied in the present study most likely also stains archaea. However, since the frequently used term 'prokaryotes' does not refer to a monophyletic group (Pace 2006), we decided to retain the term bacteria (although some archaea may have also been counted) throughout the text.

Samples were taken every $12 \mathrm{~h}\left(\mathrm{~T}_{0}\right.$ to $\left.\mathrm{T}_{5}\right)$, fixed with formaldehyde ( $2 \%$ final concentration) and processed immediately for enumeration. From these samples, $10 \mathrm{ml}$ were filtered onto $3 \mu \mathrm{m}$ Isopore membrane filters (TSTP, Millipore) to retain the particle-associated microbial fraction. Filters with particles were fixed $(2 \%$ formaldehyde final concentration) in $4.5 \mathrm{ml}$ of $0.02 \mu \mathrm{m}$ filtered water and processed immediately. To enumerate bacteria and viruses on particles, $500 \mu \mathrm{l}$ of sodium tetrapyrophosphate (5 $\mathrm{mM}$ final concentration) was added to the samples. During incubation for $1 \mathrm{~h}$, the samples were gently shaken at $20^{\circ} \mathrm{C}$. After treatment with sodium tetrapyrophosphate, the samples were sonicated $3 \times$ for $1 \mathrm{~min}$, with pulsing at $40 \mathrm{~W}$ using a B. Braun Diessel Biotech Sonifier (Labsonic U) adopted from Danovaro et al. (2001). To stain and count fixed samples, 1 to $3 \mathrm{ml}$ were filtered onto Whatman AnoDisc filters $(0.02 \mu \mathrm{m}, 25 \mathrm{~mm}$ diameter $)$. Free-living (directly filtered from the original samples) and particle-attached (after sonication) bacteria as well as viruses were stained with SYBR Gold and enumerated within $10 \mathrm{~h}$ after sampling (Chen et al. 2001). Microorganisms were enumerated under an epifluorescence microscope (Nikon E 800) at $1250 \times$ magnification. On each filter, 20 fields were counted to determine the total number of bacteria and viruses. To estimate a potential bias in virus counting due to extracellular DNA interference, the effect of DNase treatment on samples was tested (Danovaro et al. 2001). The number of viruses obtained from DNase-treated samples did not differ significantly from those obtained from untreated samples ( $\mathrm{p}>0.60$, Mann-Whitney $U$-test, $\mathrm{n}=$ 88). All counts were performed as soon as possible (within $10 \mathrm{~h}$ ) to minimize potential loss of viruses during storage.

In the literature, attached microorganism abundance is often given in cells $\mathrm{ml}^{-1}$. Since we used various particle types in different amounts, we decided to express microorganism abundance in ( $g$ dry $w t)^{-1}$ of suspended matter. Water samples from the tanks were filtered through precombusted and preweighed $\left(\mathrm{W}_{0}\right)$ glass microfiber filters (APFF Millipore GF/F, $47 \mathrm{~mm}$ diameter). The filters were dried at $60^{\circ} \mathrm{C}$ for $24 \mathrm{~h}$ and weighed again $\left(\mathrm{W}_{1}\right)$. The dry weight of the particulate matter (DW) was determined as $\mathrm{W}_{1}-\mathrm{W}_{0}$.

Bacterial secondary production (BSP) and specific BSP. BSP was measured using the thymidine ([methyl$\left.{ }^{3} \mathrm{H}\right] \mathrm{TdR}$ ) incubation method and calculated using the conversion factor described by Berger et al. (1995). Measurements were performed in triplicate, and duplicate formaldehyde-killed samples served as controls. For extraction, the samples were first transferred onto $3.0 \mu \mathrm{m}$ membrane filters (Millipore SSWP, $47 \mathrm{~mm}$ diameter) and filtered into acid-washed and rinsed glass tubes; this retains the particulate material and the associated microorganisms on the filter. These filters were washed with ice-cold trichloroacetic acid (TCA) and transferred into scintillation vials for further processing. The collected filtrate was then filtered again onto $0.45 \mu \mathrm{m}$ membrane filters (Millipore HAWP, $47 \mathrm{~mm}$ diameter), and the filters were extracted as explained above for $3.0 \mu \mathrm{m}$ filters. This method yields direct estimates of BSP of both bacterial fractions - the particle-associated $(>3 \mu \mathrm{m})$ and the free-living ( 0.45 to $3 \mu \mathrm{m}$ ) fraction (Peduzzi \& Schiemer 2008). The specific $\left(\right.$ cell $\left.^{-1}\right)$ BSP (sBSP) was calculated by dividing bacterial production with the corresponding bacterial abundance.

Statistical analyses. For all statistical analyses, we used SPSS 12.0 for Windows. Initial viral abundances were characterized by the initial abundances $\left(T_{0}\right)$ of free-living and attached viruses $\left(\log _{10}\right.$ transformed abundance values+1).

The outcome of the experiments was characterized by the changes in bacterial abundance and productivity during the course of the experiment (abundance, sBSP and BSP of both free-living and attached bacteria). These variables were calculated as follows: for bacterial parameters, endpoint values were calculated $\left(\mathrm{T}_{\text {final }}=\right.$ mean of values at $\mathrm{T}_{3}$ to $\mathrm{T}_{5}$, i.e. the saturation 
phase of the growth curve); the difference between the starting value at $\mathrm{T}_{0}$ and the endpoint value was expressed as a proportion of the initial value for parameters associated with free-living bacteria (abundance changes, changes in specific and total production; in contrast to simple ratios, the resulting indices give increasing and decreasing values equal to weight); for variables associated with attached bacteria, the proportional change values described above were multiplied by 100 (by 1000 for sBSP) and the absolute value was $\log _{10}$ transformed (this multiplication transforms values to $>1$, thus avoiding disproportional effects due to negative log values); each log transformed value was multiplied by +1 for increasing and -1 for decreasing change $(\Delta)$ values.

The different treatment of variables for attached bacteria was necessary because variables associated with attached bacteria changed over several orders of magnitude during the experiments (which was not the case for free-living bacteria); then, resulting indices had similar ranges as the other variables.

A principal component analysis (PCA) was performed on variables describing the outcome of the experiments. The number of factors was determined by the Kaiser-criterion. Factors were varimax-rotated to facilitate the interpretation of the factor loadings.

A 2-step regression analysis was carried out. In step one, the effect of particle quality on initial viral abundances (after mixing the components in the experimental tanks) and the outcome of the experiment derived from the PCA-axes described above was evaluated; this involved 5 regressions with dummy coded particle qualities ( 4 variables for the particle qualities 'aged sediment', 'fresh' and 'aged' leaves, and river snow; 1 = present, 0 = absent). Fresh mineral sediment served as the reference. In a second step, the effect of particle quality on initial viral abundances and the outcome of the experiment was removed by using the residuals of the regressions described above. Three regressions were calculated, with the residuals of PCA1 to 3 as the dependent variable and the residuals of viral (free-living and attached) abundances as the independent variable.

\section{RESULTS}

\section{Effects of particle quality}

All bacterial and viral abundances at $T_{0}$ and $T_{\text {final }}$ from all experimental treatments are presented in Figs. 2 to 4 . The changes in the measured parameters that were observed during the experiments with different types of suspended matter will now be discussed.
Mineral sediment

Bacterial abundance in the water column increased in all experiments with fresh and aged suspended matter, except in the virus-rich treatment using aged sediment (Fig. 2a). The abundance of bacteria attached to mineral sediment also increased in all treatments (Fig. 2b). As expected, viral abundance in the water in the virus-free treatment remained below the detection limit (Fig. 2c). Viral abundance in the water decreased in the 2 treatments containing viruses and fresh sediment. It did not change significantly in the incubations with aged sediment in the virus-rich treatment, but increased in the low virus treatment. Viral abundance on aged sediment particles increased in all treatments, whereas it remained more or less unchanged over the course of the experiment on fresh sediment particles (Fig. 2d).

\section{Leaf litter}

Bacterial abundance in the water column increased in all experiments with aged and fresh leaf litter as suspended matter, except for the virus-rich treatment using aged material, where free-living bacteria in the water remained at a constant level (Fig. 3a). Bacterial abundance on particles increased in all experiments using aged and fresh leaf litter as particles (Fig. 3b). Again, with our method, no viruses could be detected in the water in the initially virus-free treatments (Fig. 3c). Viral abundance in the water decreased in the treatments with fresh leaf litter at both viral abundances. In the treatments with aged leaf litter, freeliving viral abundance did not change under either abundance levels. Viral abundance on fresh and aged leaf litter increased from the beginning to the end of the experiments in all incubations, but fluctuated strongly in the final phase of the experiment (Fig. 3d).

\section{River snow}

During the course of the experiments using river snow as suspended matter, bacterial abundance in the surrounding water increased in the virus-free treatment. In the virus-rich and low viral abundance treatments, bacterial numbers in the ambient water remained constant (Fig. 4a). Bacterial abundance on river snow increased in all treatments (Fig. 4b). No viruses were detected in the water of the initially virus-free treatment; a slight increase or roughly constant abundance was observed in the other 2 virus treatments (Fig. 4c). Viral abundance on river snow tended to increase but, as with leaf litter, 

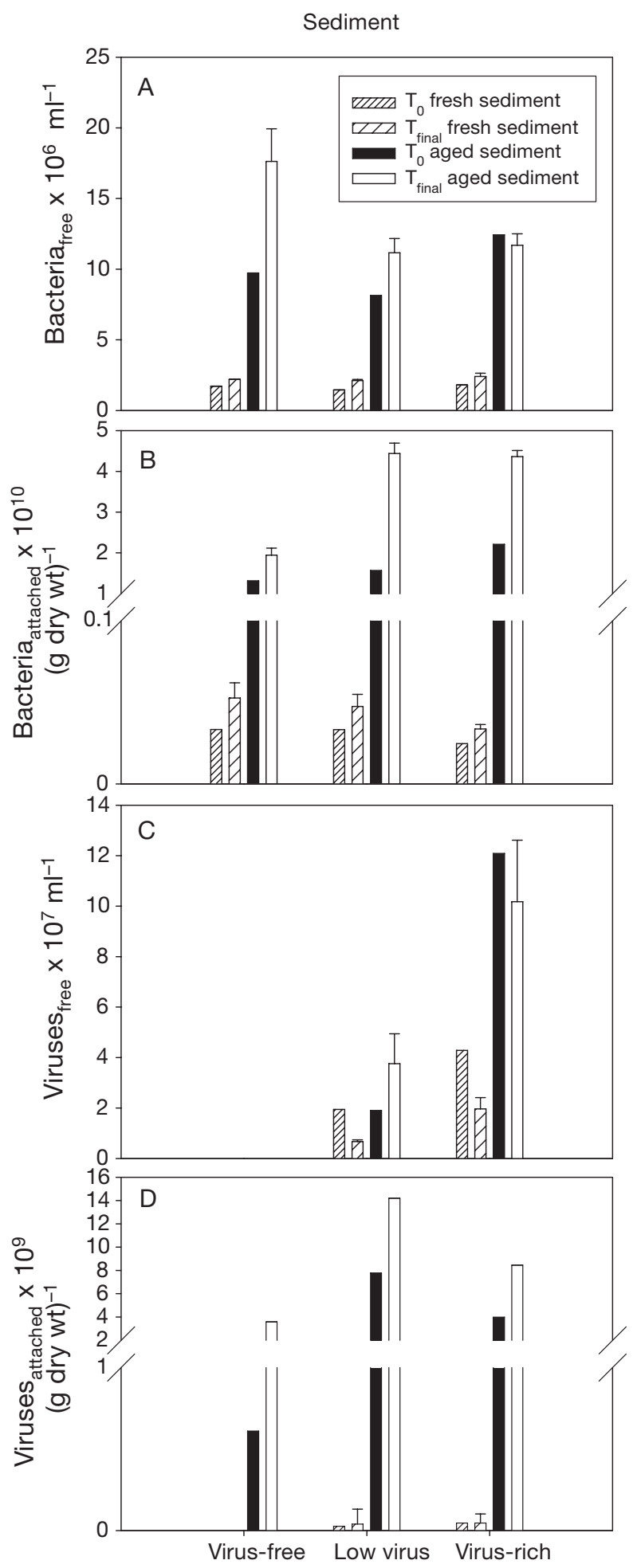

Fig. 2. Changes in the abundance $( \pm \mathrm{SE})$ of (A) free-living and (B) attached bacteria, and (C) free-living and (D) attached viruses in incubations with mineral sediments (fresh and aged) under different planktonic virus concentrations. Note different scale for values $<1$ for attached viruses and bacteria. $\mathrm{T}_{0}$ : beginning of the experiment; $\mathrm{T}_{\text {final }}$ : average of the measurements at the $36 \mathrm{th}, 48 \mathrm{th}$ and 60 th hour of the experiment
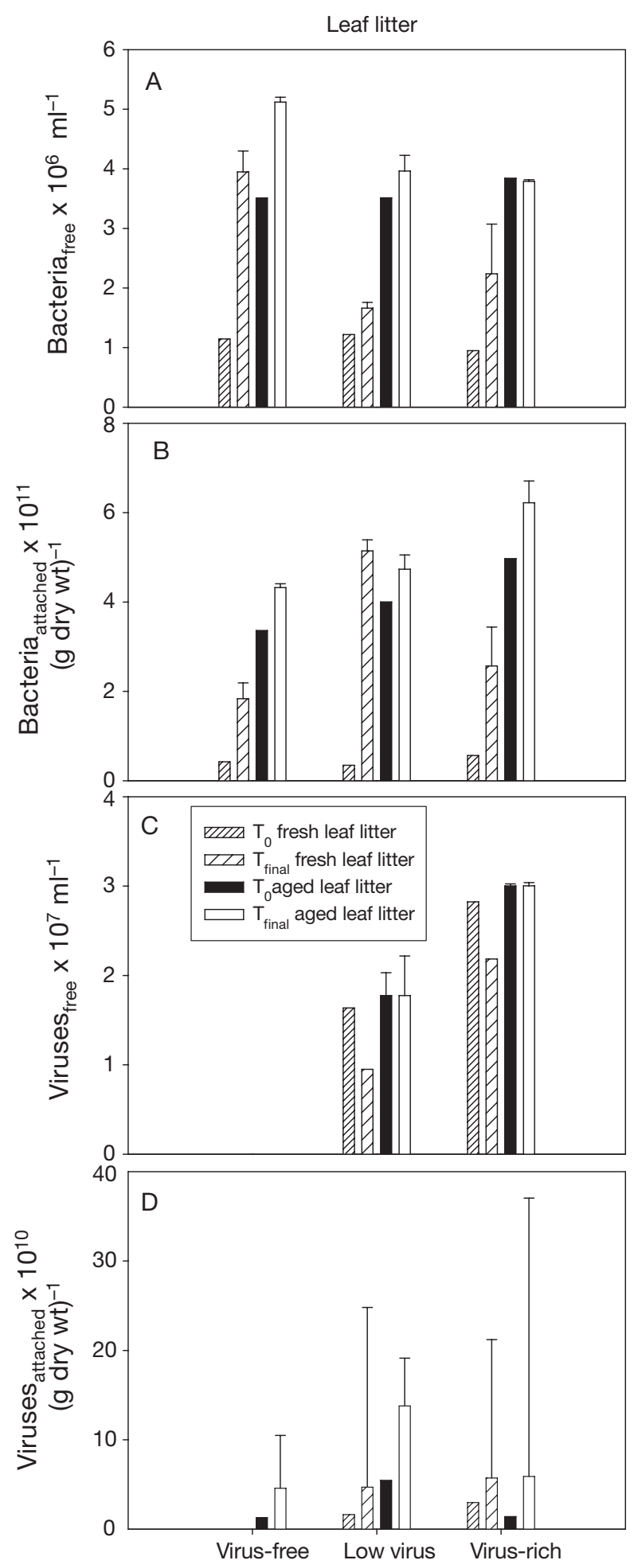

Fig. 3. Changes in the abundance $( \pm \mathrm{SE})$ of $(\mathrm{A})$ free-living and (B) attached bacteria, and (C) free-living and (D) attached viruses in incubations with leaf litter (fresh and aged) under different planktonic virus concentrations. $\mathrm{T}_{0}$ : beginning of the experiment; $\mathrm{T}_{\text {final }}$ : average of the measurements at the 36th, 48th and 60th hour of the experiment 

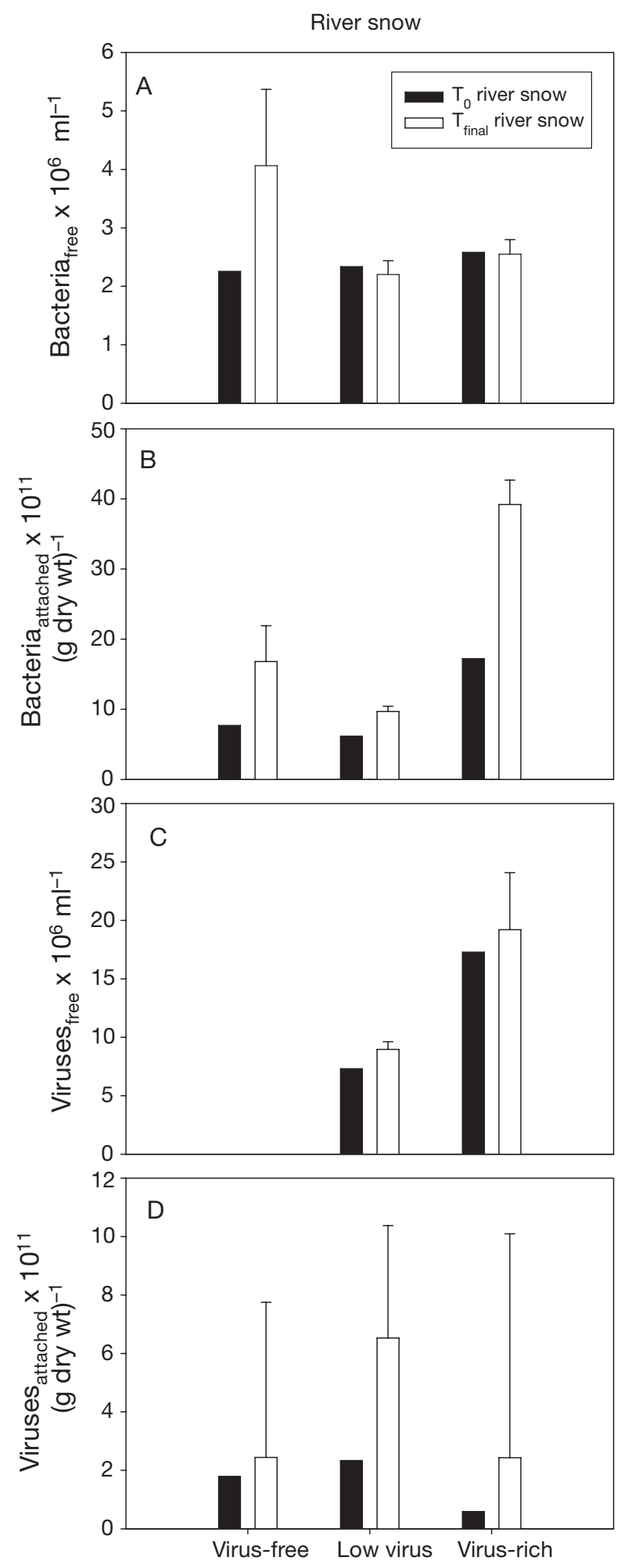

Fig. 4. Changes in the abundance $( \pm \mathrm{SE})$ of $(\mathrm{A})$ free-living and (B) attached bacteria, and (C) free-living and (D) attached viruses in incubations with river snow under different planktonic virus concentrations. $\mathrm{T}_{0}$ : beginning of the experiment; $\mathrm{T}_{\text {final }}$ : average of the measurements at the 36th, 48th and 60 th hour of the experiment

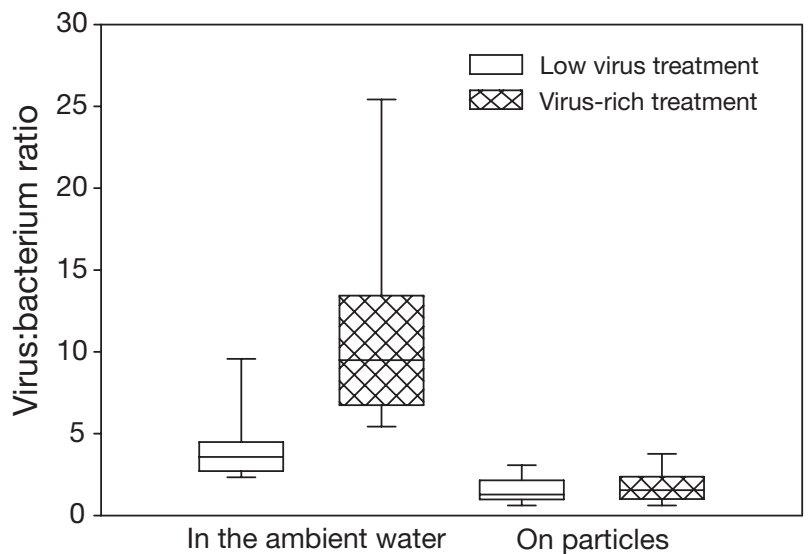

Fig. 5. Virus:bacterium ratios in the ambient water and on suspended particles at 2 different virus abundance treatments. Data presented as box plots, with the boundary of the box closest to 0 indicating the 25th percentile, the line within the box marking the median, and the boundary of the box farthest from 0 indicating the 75th percentile. Error bars: 90th and 10th percentiles

fluctuated strongly in the final phase of the experiment (Fig. 4d).

In all experimental incubations, BSP fluctuated as listed in Table 1. Both the overall $\left(\mathrm{ml}^{-1}\right.$ experimental water) as well as the specific (cell $\left.{ }^{-1}\right)$ BSP were significantly higher on particles (BSP: $\mathrm{p}<0.001, \mathrm{n}=180$; sBSP: $\mathrm{p}<0.05, \mathrm{n}=180$; Mann-Whitney $U$-test) than in bulk water. Moreover, VBR was variable during the incubations (Table 2). Generally (pooling data from all incubations), the VBR was significantly lower ( $\mathrm{p}$ 0.001, n = 180; Mann-Whitney $U$-test) on suspended matter than in bulk water (Fig. 5).

For further comparison, we analyzed potential effects of organic (leaf detritus, river snow) versus inorganic (sediment) particles as well as fresh versus aged suspended material (combined sediment and leaf litter). For this comparison, we included data on both BSP and VBR.

\section{Organic vs. inorganic particles}

The average abundance of bacteria and viruses (for both: $\mathrm{p}<0.001, \mathrm{n}=89)$ as well as the VBR $(\mathrm{p}<0.01, \mathrm{n}=$ 89; Mann-Whitney $U$-test) were significantly higher on organic than on inorganic particles. Even in the water, the abundance of bacteria was significantly higher $(\mathrm{p}<$ $0.001, \mathrm{n}=89$; Mann-Whitney $U$-test) when organic particles were present. Productivity was less affected and the effect contrasted with that on abundances: SBSP of attached bacteria was significantly higher on inorganic particles $(\mathrm{p}<0.001, \mathrm{n}=89$; Mann-Whitney $U$-test); the overall BSP was not affected. The productivity of bacte- 
Table 1. Bacterial secondary production (BSP) and specific BSP (sBSP) for the free-living and attached fractions in experiments with different particulate materials

\begin{tabular}{|c|c|c|c|c|c|c|c|c|c|c|c|c|}
\hline & \multicolumn{3}{|c|}{ 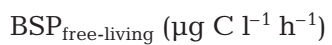 } & \multicolumn{3}{|c|}{ 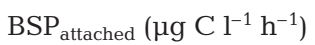 } & \multicolumn{3}{|c|}{$\operatorname{sBSP}_{\text {free-living }}\left(\mathrm{fg} \mathrm{C}_{\mathrm{C}} \mathrm{cell}^{-1} \mathrm{~h}^{-1}\right)$} & \multicolumn{3}{|c|}{$\operatorname{sBSP}_{\text {attached }}\left(\mathrm{fg} \mathrm{C} \mathrm{cell}^{-1} \mathrm{~h}^{-1}\right)$} \\
\hline & $\mathrm{N}$ & Range $A$ & Average & $\mathrm{N}$ & Range & Average & $\mathrm{N}$ & Range $A$ & Average & $\mathrm{N}$ & Range & Average \\
\hline Fresh sediment & 18 & $0.14-1.22$ & 20.69 & 18 & $0.23-2.22$ & 1.42 & 18 & $0.08-1.02$ & 0.32 & 18 & $0.28-3.48$ & $8 \quad 1.50$ \\
\hline Aged sediment & 18 & $0.24-2.47$ & 0.92 & 18 & $0.24-3.76$ & 1.93 & 18 & $0.03-0.16$ & 0.06 & 18 & $0.03-0.37$ & $7 \quad 0.16$ \\
\hline Fresh leaves & 17 & $0.04-1.40$ & 0.45 & 17 & $0.03-5.68$ & 2.28 & 17 & $0.03-0.45$ & 0.16 & 17 & $0.02-2.41$ & 10.60 \\
\hline Aged leaves & 18 & $0.48-1.26$ & 0.92 & 18 & $0.72-3.04$ & 1.80 & 18 & $0.09-0.42$ & 0.23 & 18 & $0.02-0.06$ & $\begin{array}{ll}6 & 0.04\end{array}$ \\
\hline River snow & 18 & $0.13-0.61$ & 0.35 & 18 & $0.26-1.55$ & $5 \quad 0.85$ & 18 & $0.01-0.11$ & 0.05 & 18 & $0.07-0.29$ & 90.13 \\
\hline
\end{tabular}

Table 2. Virus:bacterium ratios (VBR) for the free-living and attached fractions in experiments with different particulate materials

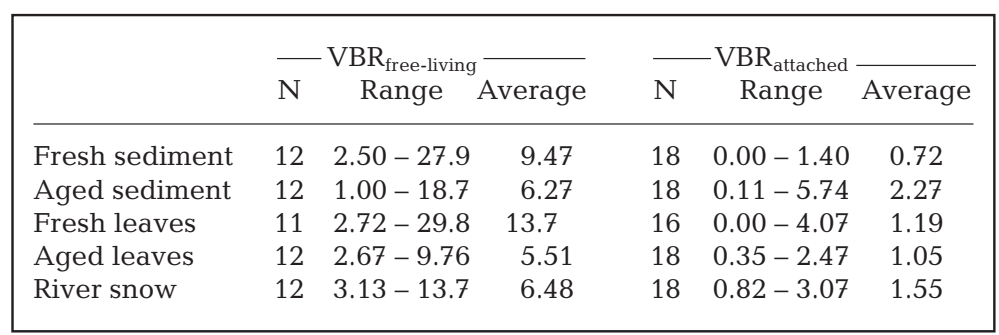

Table 3. Principal component analysis (PCA). Communalities, percentage of explained variance and factor loadings. $\mathrm{SBSP}_{\text {free: }}$ specific bacterial secondary production (BSP) of free-living bacteria; $\mathrm{BSP}_{\text {free }}$ : BSP of free-living bacteria; SBSP $_{\text {att: }}$ specific BSP of attached bacteria; $\mathrm{BSP}_{\text {att }}$ BSP of attached bacteria; bac $_{a t t}$ : abundance of attached bacteria; bac $_{\text {free }}$ : abundance of freeliving bacteria; $\Delta$ prod bac $_{\text {free: }}$ : changes in the productivity of free-living bac-

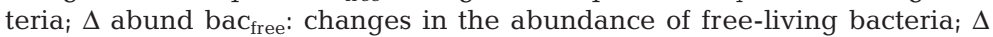
abund bac $_{a t t}$ : changes in the abundance of attached bacteria. Values in bold indicate high factor loading for respective PCA-axis

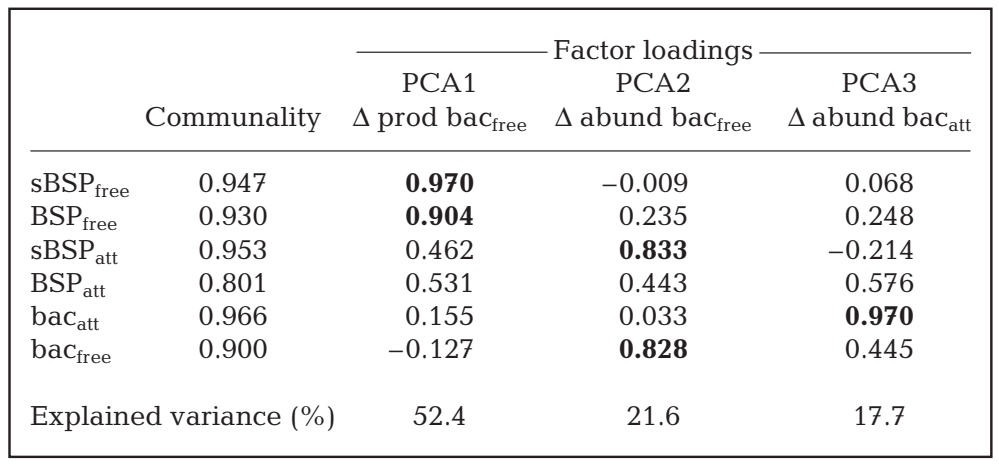

ria in the water was not significantly influenced by the presence of both organic and inorganic particles.

Fresh vs. aged particles

The average abundance of attached bacteria and viruses was significantly higher on aged particles (for both: $\mathrm{p}<0.001, \mathrm{n}=89$; Mann-Whitney $U$-test). The sBSP of attached bacteria was significantly higher on fresh particles ( $\mathrm{p}<0.001, \mathrm{n}=89$; Mann-Whitney $U$-test). In contrast to the organic versus inorganic comparison, neither the abundance and the productivity of bacteria in the water, nor the BSP and the VBR of attached and freeliving microorganisms were significantly different between fresh versus aged particles.

\section{Combined effects of particle quality and viral abundance}

The PCA, which was performed mainly to determine uncorrelated variables that describe the reaction of microorganisms during the experiments, produced the following results (Table 3 ): the 6 variables entered into the PCA (changes in abundance, sBSP and overall BSP for both free-living and attached bacteria) were transformed into 3 PCA-axes without much loss of information (in total, $91.6 \%$ of the variance in the data was explained; Table 3). The first

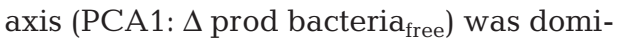
nated by the change in the productivity of free-living bacteria (both sBSP and $\mathrm{BSP}$ ), while the second (PCA2: $\Delta$ abund

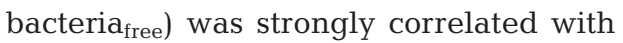
the change in the abundance of free-living bacteria and to a certain extent with the sBSP of attached bacteria. The third axis

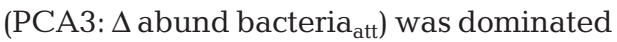
by the change in the abundance of attached bacteria. BSP of attached bacteria could not be attributed to one of the axes because the factor loadings were quite similar for all 3 axes.

Effect of particle quality on microbial parameters

Initial abundances (after mixing of the incubated components) of attached viruses were highly depen- 
Table 4. Effect of particle quality on the microbial community: initial viral abundance and changes during the experiments. Initial abund vir ${ }_{\text {att }}$ : initial abundance of attached viruses; initial abund vir free: initial abundance of free-living viruses; PCA1, 2, 3:

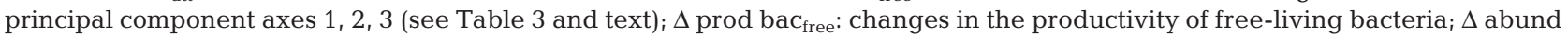
bac $_{\text {free: }}$ changes in the abundance of free-living bacteria; $\Delta$ abund bac $_{\text {att }}$ : changes in the abundance of attached bacteria; summary: parameters describing regression fit; int/sl: intercept (fresh sediment)/slope (other particle qualities). Values in bold indicate significant $(\mathrm{p}<0.05)$ parameters

\begin{tabular}{|c|c|c|c|c|c|c|c|c|c|c|}
\hline \multirow[b]{2}{*}{ Reg. coefficients } & \multicolumn{2}{|c|}{$\begin{array}{l}\text { Initial abund } \\
\text { vir }_{\text {att }}\end{array}$} & \multicolumn{2}{|c|}{$\begin{array}{l}\text { Initial abund } \\
\text { vir }_{\text {free }}\end{array}$} & \multicolumn{2}{|c|}{$\begin{array}{c}\text { PCA1 - } \Delta \text { prod } \\
\text { bac }_{\text {free }}\end{array}$} & \multicolumn{2}{|c|}{$\begin{array}{c}\text { PCA2 - } \Delta \text { abund } \\
\text { bac }_{\text {free }}\end{array}$} & \multicolumn{2}{|c|}{$\begin{array}{c}\text { PCA3 - } \Delta \text { abund } \\
\text { bac }_{\text {att }}\end{array}$} \\
\hline & Int/sl & p-value & Int/sl & p-value & Int/sl & p-value & Int/sl & p-value & Int/sl & p-value \\
\hline Fresh sediment & 0.438 & 0.439 & 0.984 & 0.066 & 1.231 & 0.028 & 0.279 & 0.662 & -0.703 & 0.025 \\
\hline Aged sediment & 1.789 & 0.042 & -0.082 & 0.905 & -1.093 & 0.139 & 0.351 & 0.697 & 2.177 & 0.000 \\
\hline Fresh leaf litter & 1.990 & 0.027 & 0.145 & 0.834 & -1.413 & 0.064 & -0.390 & 0.667 & 0.894 & 0.040 \\
\hline Aged leaf litter & 2.895 & 0.004 & -0.191 & 0.783 & -2.037 & 0.013 & -0.725 & 0.428 & -0.405 & 0.310 \\
\hline River snow & 3.694 & 0.001 & -0.257 & 0.712 & -1.611 & 0.039 & -0.634 & 0.487 & 0.847 & 0.049 \\
\hline \multirow[t]{2}{*}{ Summary: } & $\mathrm{r}^{2}$ & $\mathrm{p}$-value & $\mathrm{r}^{2}$ & $\mathrm{p}$-value & $\mathrm{r}^{2}$ & $\mathrm{p}$-value & $\mathrm{r}^{2}$ & p-value & $r^{2}$ & $\mathrm{p}$-value \\
\hline & 0.722 & 0.008 & 0.042 & 0.967 & 0.506 & 0.104 & 0.174 & 0.719 & 0.847 & 0.000 \\
\hline
\end{tabular}

dent on particle quality $\left(\mathrm{r}^{2}=0.72\right)$ (Table 4): river snow and aged leaf litter had much higher viral densities than fresh sediment. Since the initial abundance of planktonic viruses was experimentally manipulated, it could not be explained by particle quality.

To reduce the number of variables and avoid problems stemming from the colinearity of the variables, we used the 3 PCA-axes described above to represent the changes in the abundance and productivity parameters of attached and free-living bacteria. Abundance changes in attached bacteria during the experiment (PCA3) were clearly influenced by particle quality $\left(\mathrm{r}^{2}=0.85\right)$ : aged sediment favored increasing abundances. Abundance changes of free-living bacteria (PCA2) could not be attributed to particle quality, although productivity changes of free-living bacteria (PCA1) showed a relatively high, but not significant correlation with particle quality $\left(\mathrm{r}^{2}=0.51\right)$.

Based on the hypotheses formulated in the introduction, we applied a second series of regression analyses (see 'Materials and methods' for details of calculations) as discussed in the next section.

\section{Effects of initial viral abundance}

When the effect of particle quality was eliminated by using the residuals of the regressions, the initial viral abundances did not significantly explain the changes in bacterial abundance in the water and on particles (residuals from PCA2 and PCA3), but they clearly influenced the bacterial productivity in the ambient water (residuals from PCA1). The initial abundance of free-living viruses had a highly significant negative influence on bacterial productivity in the ambient water, while that of attached viruses had a highly significant positive influence, i.e. free-living viruses reduced bacterial productivity in the ambient water, whereas viruses attached on particles enhanced it (Table 5).

Fig. 6 summarizes the results of the analysis: changes in the parameters of microbes attached to particles could largely be explained by particle quality $\left(\mathrm{r}^{2}>\right.$ $0.70)$, whereas viral abundances, both on the particles and in the water, did not explain the changes in abundance of the attached microbial community. In contrast, productivity changes of bacteria in the water were affected by viral abundances, whereas an effect of particle quality on this parameter cannot be confirmed. 

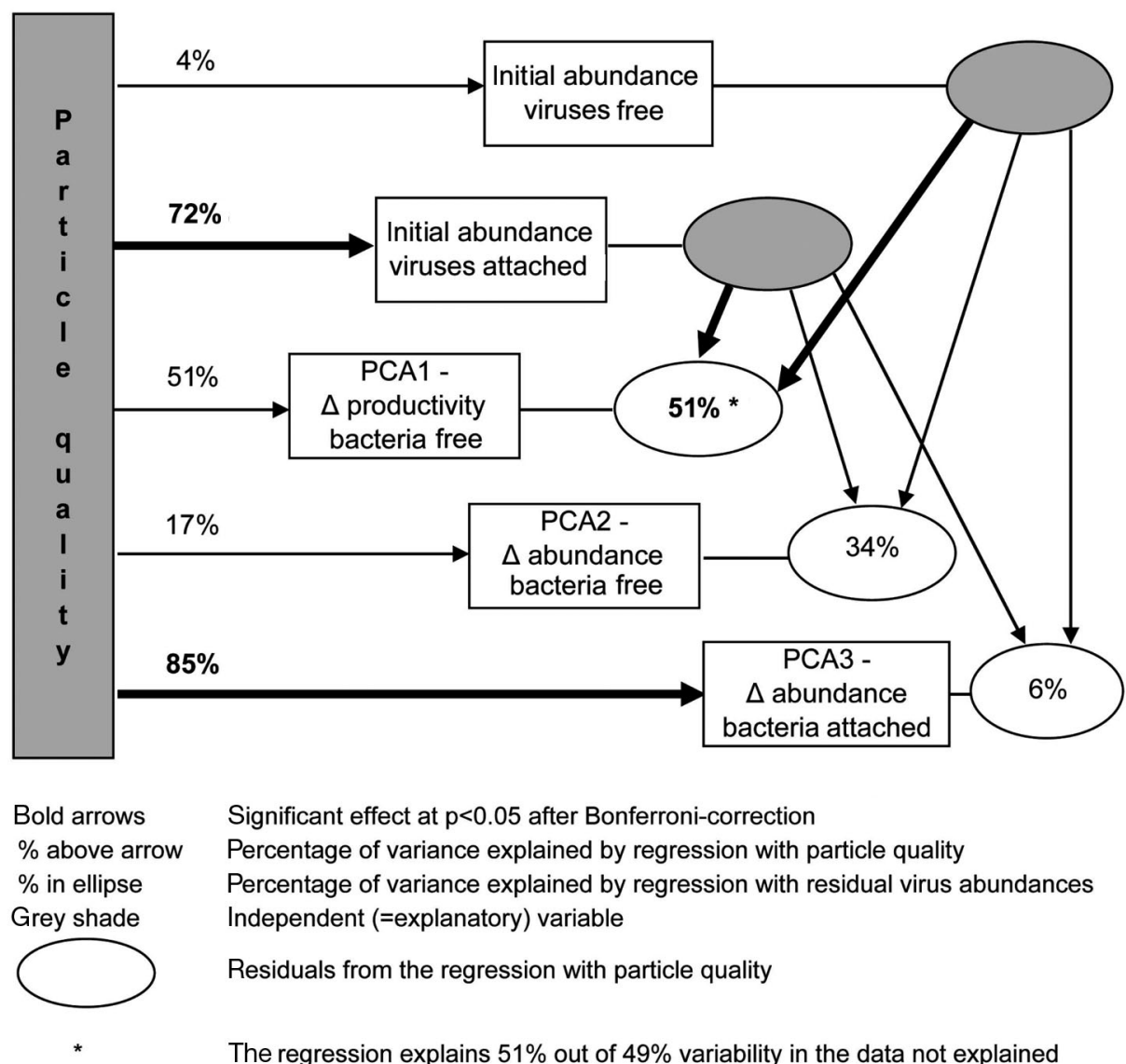

\begin{abstract}
Significant effect at $\mathrm{p}<0.05$ after Bonferroni-correction
Percentage of variance explained by regression with particle quality

Percentage of variance explained by regression with residual virus abundances

Independent (=explanatory) variable
\end{abstract}

Residuals from the regression with particle quality

The regression explains $51 \%$ out of $49 \%$ variability in the data not explained

by the regression with particle quality; analogous for the two other regressions

Fig. 6. Summary of 2-step regression analysis: on the left side are the effects of particle quality on the outcome of the experiments (represented by 3 PCA axes), on the right side is the influence of virus abundance, when particle quality is not considered (using residuals) (see 'Materials and methods', 'Statistical analyis' for details). Percentages printed in bold indicate significant regressions. Numbers in ellipses refer to the percentage of the variance explained by the second regression series alone (e.g. $51 \%$ for the regression of residual PCA1 vs. virus abundances)

\section{DISCUSSION}

Throughout our experiments, the bacterial and viral abundances on particles (when calculated as cells or viruses $\mathrm{ml}^{-1}$ ) were comparable with values reported earlier for the Danube River and the Danube floodplains (Luef et al. 2007). Such data are clearly influenced by the variable abundance of particles. Unfortunately, no bacterial or viral abundance estimates based on g dry weight of suspended particles could be found for the Danube in the literature. However, the load of suspended matter transported in the Danube varies considerably, and high discharge rates are typically associated with higher particle loads.

In general, suspended matter quality determined viral and bacterial abundance on particles. We found that viral abundance on organic and on aged particles was significantly higher than on inorganic and fresh particles. Abundances of bacteria on particles followed the same pattern, although the VBR was higher only on organic particles. In natural aquatic environments, particle quality apparently influences microbial colonization (Luef et al. 2007, Peduzzi \& Luef 2008, Riemann \& Grossart 2008). The aged and organic particles in our experiments were likely a more favorable microenvironment (at least initially). This could be due to an already formed biofilm, adsorbed organic material, or the presence of an organic matrix, which may stimulate prokaryote production and increase infection (cf. Weinbauer et al. in press). There is evidence that the higher numbers of particle-associated prokaryotes on aged particles typically exhibit higher hydrolytic activity; even the high metabolic activities of heterotrophic eukaryotes result in elevated dissolved organic 
matter (DOM) and inorganic nutrient concentrations in the pore water or at the interface of particulate matter compared to the surrounding water (Simon et al. 2002). This can result in higher host abundance and higher viral production rates. Further, Peduzzi \& Luef (2008) found a significant interrelationship between the cell ${ }^{-1}$ productivity of bacteria and viral abundance in a floodplain rich in aged particles with abundant organic constituents. All these considerations may explain why fresh and inorganic particles harbored fewer bacteria and viruses in our experiments.

The generally lower VBRs on particles relative to the bulk water from our experiments are in agreement with values from various particle environments. In freshwater sediments, values are typically lower; ratios of up to 13 have been found on floating particles in river systems (Luef et al. 2007, Peduzzi \& Luef 2009). In lake snow, VBRs varied between 0.3 and 8.5 with an average of 4.7 (Simon et al. 2002). Potential reasons for this observation are extensively discussed in Weinbauer et al. (in press).

Suspended matter quality is obviously also a strong determining factor for changes in microbial abundance. During the present experiments, the abundance of attached bacteria increased strongly on aged sediment or on organic material such as leaves and river snow. In the literature, growth rates of bacteria on organic particles mainly concern bacteria associated with marine snow and apparently vary greatly; rates may vary with the age and state of decomposition of the marine snow (Alldredge et al. 1986, Alldredge \& Gotschalk 1990). In our study, even bacterial abundance in the ambient water was influenced by particle quality: in the treatments with organic particles, bacterial abundance was on average much higher than in treatments containing inorganic particles. Thus, our experiments demonstrate that favorable growth conditions for bacteria were provided in association with particulate material, which agrees with several other studies in various aquatic environments (Grossart et al. 2007, Peduzzi \& Schiemer 2008, Besemer et al. 2009). Attached bacteria were also found to be more active (on a cell ${ }^{-1}$ basis) in a study conducted in the same Danube floodplain system where our water samples were collected. There, the sBSP was on average $9 \times$ higher than that of free-living forms (Luef et al. 2007, Peduzzi \& Luef 2008). Moreover, in an isolated backwater of the Danube River, we found a positive relation between sBSP and viral abundance (Peduzzi \& Luef 2008). Interestingly, the sBSP (i.e. the cell ${ }^{-1}$ productivity) of attached bacteria was higher in our experiments on inorganic and fresh versus organic and aged particles. One potential explanation is that the cell ${ }^{-1}$ activity has reached a saturation phase on already colonized particles compared to 'pioneering' bacteria in the ini- tial phase of colonization. Grossart \& Ploug (2000) also found reduced growth efficiency of bacteria on aged compared to fresh aggregates.

The productivity changes during the experiments revealed that the sBSP and BSP in the ambient water followed similar patterns as indicated by their high correlation with PCA1, whereas the sBSP and BSP of attached bacteria could not be allocated to the same axis, i.e. did not have the same trends. This is in accordance with the findings described for the pooled data. On the other hand, we detected no significant effect of particle quality on any of the productivity change variables.

From a physical standpoint, viruses can be regarded as charged hydrophilic colloids with some ability to adsorb to the surfaces of suspended particulate matter. From the older literature, there are indications that as much as $99 \%$ of the viruses present in coastal marine waters are adsorbed to naturally occurring colloidal and particulate matter (Berg 1973). Chattopadhyay \& Puls (2000) have shown that van der Walls forces can govern the process of sorption of selected bacteriophages on clays. Moreover, the attraction between a viral particle and any interface appears to be strongly influenced by the virus's amphipathicity, which is the result of localized hydrophobic and hydrophilic regions on the surfaces of the capsid protein, as well as by the ionic strength of the suspending medium (Thompson \& Yates 1999). This implies that even physical forces can be an important determining factor in the colonization process. In our experiments, the different types of suspended particulates apparently harbored a certain fraction of the viruses, even shortly after the mixing of the components in the incubations. However, the abundance of viruses on particles differed, depending on the quality of the material. In an environmental study of the Danube floodplain area, we found that, as particles with significant organic constituents increase in abundance, more viruses are attached and fewer are freely suspended (Peduzzi \& Luef 2008). Therefore, such particles apparently have a significant potential to remove virus-like particles (VLPs) from the water column.

Even after eliminating the effect of particle quality in our statistical analysis, variable viral abundance (both attached and free-living) affected the change in bacterial productivity in the ambient water: the abundance of planktonic viruses had a negative effect whereas that of attached viruses had a positive effect. Other studies also report a negative effect of abundant freeliving viruses on the productivity of bacteria sharing the same microhabitat (compare Peduzzi \& Weinbauer 1993b, Peduzzi \& Luef 2009). On one hand, high viral abundance on particles may enhance nutrient release due to lysis of attached hosts or lysozymes. On the 
other hand, suspended particles may act as adsorbing agents that remove viruses from the ambient water, thus lowering the probability of new infections. The few studies that simultaneously measured viral abundance and bacterioplankton production found significant correlations (Heldal \& Bratbak 1991, Maranger \& Bird 1995). A direct indication that increased viral production coincides with elevated levels of BSP was noted by Steward et al. (1996). Their study reported a significant correlation between the frequency of visibly infected cells and bacterial production rates. Accordingly, an abundant virioplankton community is probably dependent on an active bacterioplankton host community (Wommack \& Colwell 2000). A recent study by Riemann \& Grossart (2008) speculates that, in environments rich in particulate matter, elevated lytic production of phages occurs due to increased activities of particle-associated bacteria.

The results presented here supplement the scarce observations that particle-associated viruses exhibit some dependency on the type and quality of the material (Farnell-Jackson \& Ward 2003, Luef et al. 2007, Peduzzi \& Luef 2008). In this context, the effect of suspended particles can be ecologically significant. For example, a study conducted in the Gulf of Mexico reports that free-living viruses may bind irreversibly to aggregates, thereby losing their infectivity (Suttle \& Chen 1992). There is also evidence, however, that viral association with colloidal and particulate material can prolong their survival (Kapuscinski \& Michell 1980), and phage production and transduction frequency may even increase in the presence of particulate matter (Kokjohn et al. 1991, Ripp \& Miller 1995). Based on our own results, we argue that not only the availability but also the quality of the suspended particles will be crucial for the survival and/or proliferation of viruses in aquatic environments.

In conclusion, the present laboratory experiments supported our main hypotheses: both seston quality and variable viral abundances in the bulk water considerably influence microbial parameters. This suggests a potential effect of variable particle quality and viral abundance on microbial parameters in natural aquatic environments. We cautiously use the term 'potential' because experimental results have to be translated with care to natural conditions. Enclosure experiments may be biased due to unknown effects stemming from e.g. confinement, handling or the walls of the containers. However, since the volume of our tanks was relatively large $(10 \mathrm{l})$, the jars were kept rotating to keep all material in suspension, and all treatments were run at identical initial conditions (except for the intended different treatments), our statistically significant results should be relevant for in situ processes. These experimental results will hope- fully stimulate further investigations, including in situ ones, on suspended matter and viral particles in riverine systems. Future studies should collect information on virus-mediated bacterial mortality to better understand whether attached viruses correspond to planktonic forms that were previously adsorbed, or if they were produced locally from infected attached bacteria. Exploring this question will require additional estimates of viral production in ambient water and on particulate material. Focusing on such topics will provide further key insights into the structure and function of aquatic systems.

Acknowledgements. We thank M. G. Weinbauer for valuable discussions, B. Luef and M. Agis for all kinds of help in the laboratory, and M. Maschek for drawing Fig. 1. The Austrian Science Fund supported our research (grants P14721 and 17798 to P.P.).

\section{LITERATURE CITED}

Alldredge AL, Gotschalk C (1990) The relative contribution of marine snow of different origins to biological processes in coastal waters. Cont Shelf Res 10:41-58

Alldredge AL, Cole JJ, Caron DA (1986) Production of heterotrophic bacteria inhabiting macroscopic organic aggregates (marine snow) from surface waters. Limnol Oceanogr 31:68-78

Auguet JC, Montanié H, Hartmann HJ, Lebaron P, Casamayor EO, Catala P, Delmas D (2009) Potential effect of freshwater virus on the structure and activity of bacterial communities in the Marennes-Oléron bay (France). Microb Ecol 57:295-306

Berg G (1973) Removal of viruses from sewage, effluents and waters. Present and future trends. Bull WHO 49:461-469

Berger B, Hoch B, Kavka G, Herndl GJ (1995) Bacterial metabolism in the River Danube: parameters influencing bacterial production. Freshw Biol 34:601-616

Besemer K, Moeseneder MM, Arrieta JM, Herndl GJ, Peduzzi $P$ (2005) Complexity of bacterial communities in a riverfloodplain system (Danube, Austria). Appl Environ Microbiol 71:609-620

Besemer K, Agis M, Eichberger B, Luef B, Preiner S, Peduzzi P (2009) Sources and composition of organic matter as substrate for bacterial growth in a large European riverfloodplain system (Danube, Austria). Org Geochem 40: 321-331

Chattopadhyay S, Puls RW (2000) Forces dictating colloidal interactions between viruses and soil. Chemosphere 41 : 1279-1286

Chen F, Lu JR, Binder B, Liu YC, Hodson RE (2001) Application of digital image analysis and flow cytometry to enumerate marine viruses stained with SYBR Gold. Appl Environ Microbiol 67:539-545

Danovaro R, Dell'Anno A, Trucco A, Serresi M, Vanucci S (2001) Determination of virus abundance in marine sediment. Appl Environ Microbiol 67:1384-1387

Farnell-Jackson EA, Ward AK (2003) Seasonal patterns of viruses, bacteria and dissolved organic carbon in a riverine wetland. Freshw Biol 48:841-851

Grossart HP, Ploug H (2000) Bacterial production and growth efficiencies: direct measurements on riverine aggregates. Limnol Oceanogr 45:436-445 
Grossart HP, Tang KW, Kørboe T, Ploug H (2007) Comparison of cell-specific activity between free-living and attached bacteria using isolates and natural assemblages. FEMS Microbiol Lett 266:194-200

- Hein T, Heiler G, Pennetzdorfer D, Riedler P, Schagerl M, Schiemer F (1999) The Danube restoration project: functional aspects and planktonic productivity in the floodplain system. Regul Rivers Res Manage 15:259-270

Hein T, Baranyi C, Herndl GJ, Wanek W, Schiemer F (2003) Allochthonous and autochthonous particulate organic matter in floodplains of the River Danube: the importance of hydrological connectivity. Freshw Biol 48:220-232

Heldal M, Bratbak G (1991) Production and decay of viruses in aquatic environments. Mar Ecol Prog Ser 72: 205-212

> Hopkinson CS, Buffam I, Hobbie J, Vallino J and others (1998) Terrestrial inputs of organic matter to coastal ecosystems: an intercomparison of chemical characteristics and bioavailability. Biogeochemistry 43:211-234

Johnson BD, Zhou X, Wangersky PJ (1986) Surface coagulation in sea water. Neth J Sea Res 20:201-210

Kapuscinski RB, Michell R (1980) Processes controlling virus inactivation in coastal waters. Water Res 14:363-371

Kokjohn TA, Sayler GS, Miller RV (1991) Attachment and replication of Pseudomonas aeruginosa bacteriophages under conditions simulating aquatic environments. J Gen Microbiol 137:661-666

Luef B, Aspetsberger F, Hein T, Huber F, Peduzzi P (2007) Impact of hydrology on free-living and particle-associated microorganisms in a river floodplain system (Danube, Austria). Freshw Biol 52:1043-1057

Luef B, Neu TR, Peduzzi P (2009) Imaging and quantifying virus fluorescence signals on aquatic aggregates: a new method and its implications for aquatic microbial ecology. FEMS Microbiol Ecol 68:372-380

Maranger R, Bird DF (1995) Viral abundance in aquatic systems: a comparison between marine and fresh waters. Mar Ecol Prog Ser 121:217-226

Neu TR (2000) In situ cell and glycoconjugate distribution in river snow studied by confocal laser scanning microscopy. Aquat Microb Ecol 21:85-95

Pace NR (2006) Time for a change. Nature 441:289

Peduzzi P, Luef B (2008) Viruses, bacteria and suspended particles in a backwater and main channel site of the Danube (Austria). Aquat Sci 70:186-194

Peduzzi P, Luef B (2009) Viruses. In: Likens GE (ed) Encyclopedia of inland waters. Vol 3. Elsevier, Oxford, p 279-294

Peduzzi P, Schiemer F (2008) Bacterial dynamics, nutrients and organic matter in the water column of tropical freshwater reservoirs of Sri Lanka. In: Schiemer F, Simon D, Amarasinghe U, Moreau J (eds) Aquatic ecosystems and development: comparative asian perspectives. Bakhuysen Publishers, p 135-152

Peduzzi P, Weinbauer MG (1993a) Effect of concentrating the virus-rich $2-200 \mathrm{~nm}$ size fraction of seawater on the formation of algal flocs (marine snow). Limnol Oceanogr 38: $1562-1565$

Peduzzi P, Weinbauer MG (1993b) The submicron size fraction of seawater containing high numbers of virus parti-

Editorial responsibility: Gunnar Bratbak, Bergen, Norway cles as bioactive agent in unicellular plankton community successions. J Plankton Res 15:1375-1386

Peduzzi P, Aspetsberger F, Hein T, Huber F, Kargl-Wagner S, Luef B, Tachkova Y (2008) Dissolved organic matter (DOM) and bacterial growth in floodplains of the Danube River under varying hydrological connectivity. Fund Appl Limnol/Arch Hydrobiol 171:49-61

Proctor LM, Fuhrman JA (1990) Viral mortality of marine bacteria and cyanobacteria. Nature 343:60-62

Proctor LM, Fuhrman JA (1992) Mortality of marine bacteria in response to enrichments of the virus size fraction from seawater. Mar Ecol Prog Ser 87:283-293

Riemann L, Grossart HP (2008) Elevated lytic phage production as a consequence of particle colonization by a marine Flavobacterium (Cellulophaga sp.). Microb Ecol 56: 505-512

Ripp S, Miller RV (1995) Effects of suspended particulates on the frequency of transduction among Pseudomonas aeruginosa in a freshwater environment. Appl Environ Microbiol 61:1214-1219

> Shanks AL, Edmondson EW (1989) Laboratory-made artificial marine snow: a biological model of the real thing. Mar Biol 101:463-470

Simon M, Grossart HP, Schweitzer B, Ploug H (2002) Microbial ecology of organic aggregates in aquatic ecosystems. Aquat Microb Ecol 28:175-211

> Steward GF, Smith DC, Azam F (1996) Abundance and production of bacteria and viruses in the Bering and Chukchi Seas. Mar Ecol Prog Ser 131:287-300

- Suttle CA, Chen F (1992) Mechanisms and rates of decay of marine viruses in seawater. Appl Environ Microbiol 58: 3721-3729

Suttle CA, Chan AM, Cottrell MT (1990) Infection of phytoplankton by viruses and reduction of primary productivity. Nature 347:467-469

Suttle CA, Chan AM, Cottrell MT (1991) Use of ultrafiltration to isolate viruses from seawater which are pathogens of marine phytoplankton. Appl Environ Microbiol 57: 721-726

Thompson SS, Yates MV (1999) Bacteriophage inactivation at the air-water-solid interface in dynamic batch systems. Appl Environ Microbiol 65:1186-1190

Ward GM, Ward AK, Dahm CN, Aumen NG (1990) Origin and formation of organic and inorganic particles in aquatic systems. In: Wotton RS (ed) The biology of particles in aquatic systems. CRC Press, Boca Raton, FL, p 27-56

Weinbauer MG (2004) Ecology of prokaryotic viruses. FEMS Microbiol Ecol 28:127-182

Weinbauer MG, Suttle CA (1996) Potential significance of lysogeny to bacteriophage production and bacterial mortality in coastal waters of the Gulf of Mexico. Appl Environ Microbiol 62:4374-4380

Weinbauer MG, Bettarel I, Cattaneo R, Luef B and others (in press) Viral interactions with organic and inorganic particles in the water column: implications for aquatic microbial ecology. Aquat Microb Ecol doi:10.3354/ame01363

Wommack KE, Colwell RR (2000) Virioplankon: viruses in aquatic ecosystems. Microbiol Mol Biol Rev 64:69-114

Submitted: December 5, 2008; Accepted: June 23, 2009

Proofs received from author(s): September 18, 2009 